\title{
Review Article \\ Competing in the Global LED Industry: The Case of Taiwan
}

\author{
Yu-Shan Su \\ Department of Industrial Education, National Taiwan Normal University, No. 162, He-Ping E. Road, Taipei 106, Taiwan \\ Correspondence should be addressed to Yu-Shan Su; yssu@ntnu.edu.tw
}

Received 2 April 2014; Revised 19 May 2014; Accepted 19 May 2014; Published 5 June 2014

Academic Editor: Ho Chang

Copyright (C) 2014 Yu-Shan Su. This is an open access article distributed under the Creative Commons Attribution License, which permits unrestricted use, distribution, and reproduction in any medium, provided the original work is properly cited.

\begin{abstract}
Light-emitting diode (LED) is a very essential application for energy-savings nowadays. The revenue of the Taiwan LED components industry is ranked top one in the world, followed by that of Japan and South Korea. Based on the advantage of their electronics industry, Taiwanese LED companies create a unique model to compete with the international firms. Large international LED companies achieve economies of scale by vertically integrating their operations. Taiwanese LED companies specialize and achieve an optimal efficiency by vertically disintegrating across the upstream, midstream, and downstream sectors in the value chains. Taiwanese LED companies create economies of scale and economies of scope through a complete industrial value chain.
\end{abstract}

\section{Introduction}

Energy-savings are getting more and more important in recent years, since both global warming and energy reduction are getting more and more serious. Light-emitting diode (LED) is a very essential application for energy-savings nowadays. Asia is the major of the global production base for the LED industry and home to the four countries with the highest LED revenue, namely, Taiwan, Japan, South Korea, and China. In 2010, Asia accounted for $81.3 \%$ of the global market share. The revenue of global high-power LEDs reached US $\$ 10.1$ billion in 2012, with an annual growth rate of $13.4 \%$. The high-power LED market share of Taiwanese, Japanese, South Korean, and Chinese firms, when combined, amounts to $61.3 \%$ of the global total, leading the global LED industry [1].

The revenue of Taiwanese LED components industry reached US $\$ 4,673$ million in 2011 , which accounts for approximately $30 \%$ of the global total, ranking first in the world. In 2010 and 2011, not only the revenue of Taiwanese LED components industry was the highest in the world but also Taiwanese LED industry has become the leader of the global LED industry. Developed for four decades, Taiwanese firms play an important role in the global LED industry. And Taiwanese LED industry has established a complete industrial value chain. The upstream and midstream revenue was approximately US $\$ 1,800$ million and the downstream revenue was approximately US\$2,800 million 2011 [2].

Japanese firms have been the global leaders of the LED industry with its high-level technologies and capabilities for a significant length of time. In the past, Japanese firms claimed over half of the global market share. Global market share of Japanese firms declined to $41.5 \%$ in 2010 because of strong Taiwanese firms and aggressive Korean and Chinese firms. The fast-growing South Korean firms secured a market share of $10 \%$ in 2010. In 2002, Korean companies of Samsung LED and LG Innotek have aggressively expanded their LED industries and pioneered the market of liquid crystal displays (LCD) televisions with LED backlighting. The market share of Chinese firms was 5\% in 2010 and continues to grow [2].

There are numerous advantages of LEDs, such as their compact size, long lifespan, high luminous efficiency, durability, power-saving abilities, and pollution-free characteristics. Many governments worldwide have focused on the LED industry in recent years. In the future, LEDs will be used primarily for lighting purposes, such as the lighting management systems of the high-efficiency light source and the intelligent lighting systems. In Taiwan, more than 800 LEDrelated firms exist, with an employment population of over 20,000 . By 2015, the revenue of the Taiwanese LED industry 
is estimated to exceed US $\$ 18,000$ million, transforming LEDs from tiny electronic components into a leading industry that attracts worldwide attention.

This paper focuses on the LED components industry and analyzes the trends and developments of the LED industry in Taiwan and in the globe. The positioning and competitive advantage of Taiwanese firms in the global LED industry is also analyzed.

\section{Analysis of Global LED Industry}

2.1. Scope of LED Industry. Composed of semiconductor materials, LEDs combine semiconductor electrons and electron holes to emit photons that can be made into lightemitting components. The LED industry comprises the following two parts (see Figure 1): (1) the components industry, which includes epitaxies, grains, packaging, and modules, and (2) the application industry, which includes light bulbs and alternative light sources. This study focuses on the LED component industry.

The value chain of LED industry included (1) single chips and epitaxial wafer (Epi-wafer) in the upstream sector, (2) grain in the midstream sector, and (3) package and module in the downstream sector (see Figure 2).

(1) Upstream sector of Epi-wafer: where the primary products include single chip and epitaxial wafer. Wafer is formed by cutting monocrystalline silicon stick into single wafer substrates and growing material compounds on substrates using Metal Organic Chemical Vapor Deposition (MOCVD) method.

(2) Midstream sector of grain process: where the primary products are grain. Epitaxial wafer diffusion and metal evaporation are performed as required, followed by wafer masking, etching, and heat treatment to create grain electrodes. Finally, the grain is cut, tested, and inspected to complete the midstream production of grain.

(3) Downstream sector of package and module: various LED components are formed through a series of processes, including die bonding, wiring, wax sealing, and baking.

2.2. History of Global LED Industry. During the initial stage of the developments, LEDs only emitted infrared or red light with the addition of GaAs. As material sciences advanced, energy released as light was applied to produce various diodes capable of generating lights of varying colors. LEDs possess a number of advantages, such as low power consumption, durable components, radiation-free characteristics, and a compact size. As the luminous efficiency gradually improves, LEDs have become an ideal substitute for traditional lighting systems. The history of LED development is provided below (see Table 1).

In 1907, Henry Joseph Round of Radio Corporation of America first found that light-emitting components have the characteristics of a rectifier. The first components were named light-emitting diodes, abbreviated as LEDs, and published

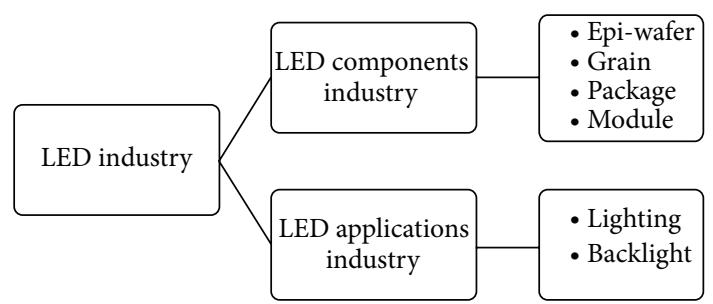

FIGURE 1: Scope of the LED industry. Source: this study.

in the journal [3]. In 1955, Rubin Braunstein of Radio Corporation of America identified the infrared radiation effects of GaAs and other semiconductor alloys for the first time. In 1962, Nick Holonyak Jr. of General Electric Company in United States developed the first light-emitting diode that could emit visible red light suitable for practical use. In 1992, Shuji Nakamura of Nichia Corporation in Japan developed the first GaN diodes. In 1995, Shuji Nakamura of Nichia Corporation successfully fabricated green- and blue-light GaN LEDs. In 1996, Shuji Nakamura proposed fabricating white-light LEDs using blue-light InGaN LEDs to excite fluorescent substances. In 1998, Nichia Corporation launched the first white LED product. In 2012, the Cree Company in United States introduced a luminous efficiency of $254 \mathrm{~lm} / \mathrm{W}$, establishing a new record of aluminous efficiency [4].

2.3. Analysis of Global LED Value Chain. The global LED market grew substantially recently. The market share of Taiwanese, Japanese, South Korean, and Chinese firms combined accounted for $81.3 \%$ of the global total in 2010 and over $80 \%$ in 2011 . The primary LED producers have been based in Asia in the world. In the future, the primary arena of the global LED industry will continue to base in Asia. And Taiwanese, Japanese, and South Korean firms will be the dominant players. The global LED value chain is analyzed below (see Figure 2).

As the established renewable energy industry drives the industrial developments of the LED industry, international giants like Philips, Sony, Hitachi, and Samsung are moving aggressively into the LED market [5]. Most large companies from Europe, the United States, Japan, and South Korea are vertically integrated companies that comprise upstream, midstream, and downstream segments. A number of global lighting conglomerates (such as Phillips Company in Netherlands and Sharp Corporation in Japan) are vertically integrated companies supplying a large variety of LED components and appliance products. Top ten global LED suppliers are listed in the following table (see Table 2) [6].

In Taiwan, labors were divided across three sectors during the initial stage, that is, upstream, midstream, and downstream sections. Subsequently, this was transformed into a two-sector model, comprising an (1) up-midstream sector of Epi-wafer and grain process and (2) downstream sector of package, with the (1) up-midstream sector of Epiwafer and grain process including the firms of Epistar, Huga, FormosaEpiraxy, Techcore and (2) the downstream sector of package including the firms of Everlight, Lite-on, and 
TABLE 1: The history of global LED industry.

\begin{tabular}{|c|c|}
\hline Year & Events \\
\hline 1907 & Henry Joseph Round, who worked in Radio Corporation of America, found the first LED of SiC and published it in a journal. \\
\hline 1955 & $\begin{array}{l}\text { Rubin Braunstein, who worked in Radio Corporation of America, identified the emitted infrared radiation of GaAs and other } \\
\text { semiconductor alloys for the first time. }\end{array}$ \\
\hline 1962 & $\begin{array}{l}\text { The first LED that could emit visible red light suitable for practical use was developed by Nick Holonyak, who worked in General } \\
\text { Electric Company. }\end{array}$ \\
\hline 1992 & Shuji Nakamura of Japanese Nichia Corporation developed the first GaN diodes. \\
\hline 1994 & Shuji Nakamura of Japanese Nichia Corporation developed fabricated green- and blue-light GaN LEDs. \\
\hline 1996 & $\begin{array}{l}\text { Shuji Nakamura of Japanese Nichia Corporation developed fabricating white-light LEDs using blue-light InGaN LEDs to excite } \\
\text { fluorescent substances. }\end{array}$ \\
\hline 1998 & Japanese Nichia Corporation launched the first white LED product. \\
\hline 2002 & The $5 \mathrm{~W}$ of LED appeared in the market, and the luminous efficiency was approximately 18 to $22 \mathrm{~lm} / \mathrm{w}$. \\
\hline 2009 & Japanese Nichia Corporation introduced a new luminous efficiency record of $249 \mathrm{~lm} / \mathrm{w}$. \\
\hline 2010 & The revenue of Taiwanese LED components industry reached US $\$ 4,554$ million and ranked top 1 in the world \\
\hline 2011 & The revenue of Taiwanese LED components reached US $\$ 4,673$ million and ranked top 1 in the world. \\
\hline 2012 & U.S. Cree Company introduced a new luminous efficiency record of $254 \mathrm{~lm} / \mathrm{W}$. \\
\hline
\end{tabular}

Source: this study.

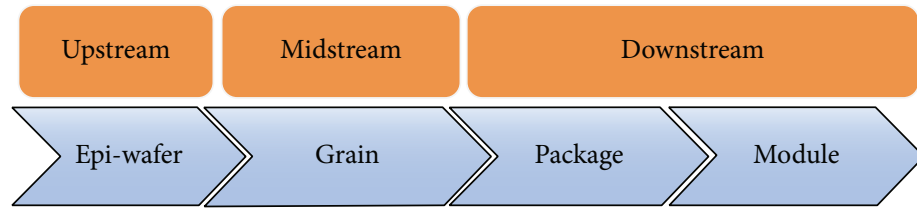

\begin{tabular}{|c|c|c|c|}
\hline \multirow{2}{*}{ 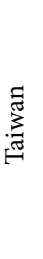 } & \multicolumn{2}{|c|}{$\begin{array}{l}\text { Epistar, Epitaxy, Arima, Huga, } \\
\text { Luxtaltek, LED Expert, Genesis }\end{array}$} & \multirow{2}{*}{$\begin{array}{l}\text { Everlight, Lite-On, Bright, UNI, } \\
\text { TrendForce, ParaLight, LiteVision, } \\
\text { EOI, Kingbright, SY, Ligitek, Rodan, } \\
\text { Oasistek, CS bright, Solidlite, NanYa }\end{array}$} \\
\hline & $\begin{array}{l}\text { Shin-Ets, } \\
\text { VPEC, } \\
\text { AET, LMOC, } \\
\text { Xing-Guang }\end{array}$ & $\begin{array}{l}\text { OPTO, Tyntek, } \\
\text { Highlight } \\
\text { Optoelectronics }\end{array}$ & \\
\hline \multirow{2}{*}{ ڤ્ } & \multicolumn{3}{|c|}{ Nichia, Rohm, Sharp } \\
\hline & \multicolumn{2}{|c|}{ Toyoda Gosei } & Citizen, Stanley, Kagoshima \\
\hline 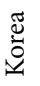 & \multicolumn{3}{|c|}{ Samsung LG, LG Innotek, Seoul Semidonductor LED } \\
\hline ڤே & \multicolumn{2}{|c|}{ Uniroyal, Cree, GelCore, AXT } & Agilent Technologies \\
\hline 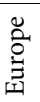 & \multicolumn{3}{|c|}{$\begin{array}{l}\text { Philip Lumileds Lighting (Netherlands), } \\
\text { Osram (Germany) }\end{array}$} \\
\hline
\end{tabular}

FIGURE 2: Value chain of global LED industry. Source: this study.

Kingbright. Also, Everlight Electronics Corporation is among the top-ten LED suppliers in the world (see Table 2) [6].

In Japan, the technological capabilities of Japanese highpower LEDs lead the global LED component industry. Nichia Corporation and Toyoda Gosei Company are the leading holders of LED patents globally. Facing low-priced competition from Taiwanese and South Korean suppliers in recent years, the market share of Japanese firms slipped to approximately $30 \%$ in 2011 , behind that of Taiwan, and ranked second in the world. In Japan, many LED firms are vertically integrated (such as Nichia, Rohm, and Sharp), with upstream suppliers including Toyoda Gosei Company and downstream suppliers including the firms of Citizen, Stanley, and Kagoshima.

In South Korea, electronics firms have gained a rapidly expanding market share in recent years because of their brand advantages. The market share of Korean firms Samsung LED, LG Innotek, and Seoul Semiconductor LED grew rapidly to $26 \%$ in 2011 , assuming the position of the third largest supplier in the world. With the support of the South Korean 
TABLE 2: Top 10 global LED components suppliers in 2013.

\begin{tabular}{llcc}
\hline Rank & Supplier & Country & $\begin{array}{c}\text { Revenue } \\
\text { (unit: million USD) }\end{array}$ \\
\hline 1 & Nichia Corporation & Japan & 2058 \\
2 & Samsung LED & Korea & 1390 \\
3 & Osram Company & Germany & 1189 \\
4 & LG Innotek & Korea & 933 \\
5 & Seoul Semiconductor & Korea & 921 \\
6 & LED & USA & 895 \\
7 & Cree Company & Philips Lumileds & Netherlands \\
\multirow{2}{*}{8} & Lighting Company & & 821 \\
9 & Toyota-Gosei & Japan & 538 \\
10 & Sharp Corporation & Japan & 486 \\
& Everlight Electronics & Taiwan & 448 \\
\hline
\end{tabular}

Source: Strategies Unlimited (2014) [5].

government, major companies such as Samsung and LG have adopted vertically integrated operations.

In United States and Europe, because of the economic downturn and sluggish global market, the market share of the U.S. and European firms, which had previously secured the high-end segment of the LED industry, comprised approximately $20 \%$ of the global market share in 2011. In the United States, up- and midstream integrated suppliers include Uniroyal, Cree, GelCor, AXT and downstream suppliers include Agilent Technologies Company. In Europe, Philip Lumileds Lighting Company of Netherlands and Osram Company of Germany are vertically integrated suppliers.

In China, the Chinese government provides subsidies to domestic firms for production equipment, land, leasing, and taxation, as well as market opportunities to foster the rapid developments of numerous Chinese LED suppliers. The revenue of the Chinese LED components industry has reached a growth rate of $24 \%$ in 2012 [6].

2.4. Revenue Scale of Global LED Industry. In 2011, the revenue of the global LED components industry (including Epiwafer, grain, and package and module) reached US\$16,600 million (see Table 3 and Figure 3) [1, 2]. Taiwanese, Japanese, and South Korean firms have become the main players of the global LED component industry, with their combined revenue accounting for $73 \%$ of the world total. In 2010, the global LED component market experienced a $6.5 \%$ recession for the first time. Driven by the rapid merging of the suppliers and a proliferating lighting market, the price of LED components remained stable in 2012, and the global components market rebounded to the 2011 level. As the performance of LEDs improves, and the energy-saving policies of the governments implement and industrial economies of scale achieve, the LED market will continue to grow in the future. The revenue is estimated to increase to approximately US $\$ 41.5$ billion by

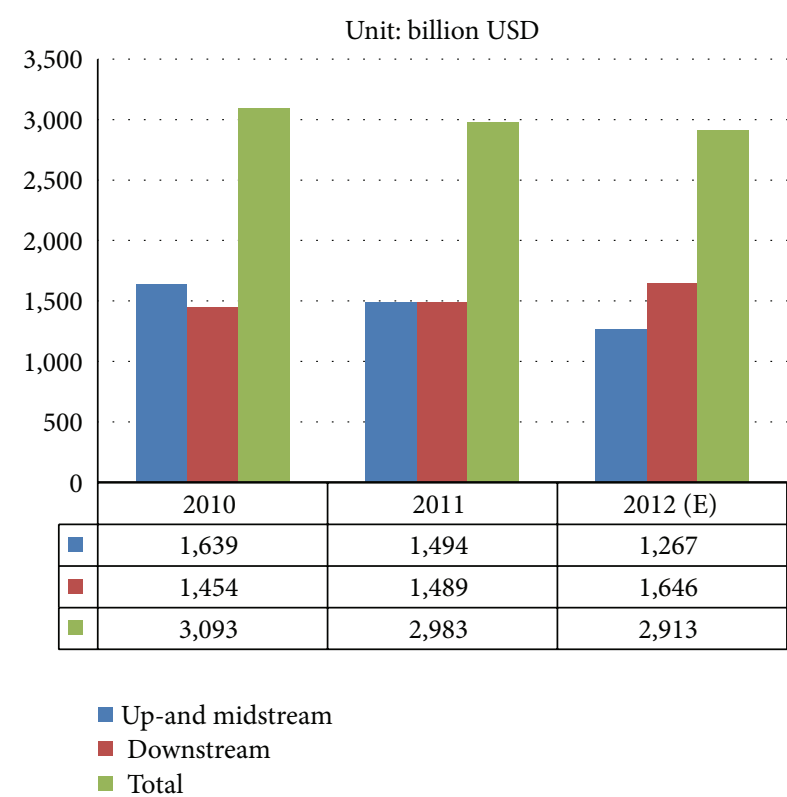

FIGURE 3: 2012 revenue of global LED industry. Source: Topology Research Institute (2012) [1]. Up- and midstream: Epi-wafer and grain. Downstream: package and module.

2016, with the rate of growth reaching 46\% between 2010 and 2016 [7].

2.5. The Relations between International Companies and Taiwanese Companies. Coopetition behavior between LED manufactures is explored by patent analysis. For example, Nichia has the advantages in the field of LED components, while Osram has the advantages in the field of phosphor [8]. There are existing cooperative opportunities for the LED manufactures because their technological capabilities are partially complementary. Since numerous LED patents are set to expire in 2012, cross-licensing will increase the strategic development of patent networks and create opportunities for late comers. Technological licensing is the only gateway into LED markets. For example, Taiwanese Epistar Corporation and Korean firms Sangsung LED, LG Innotek, and Seoul Semiconductor LED obtained technological authorization from five of the main global LED suppliers first. The relations between international LED companies and Taiwanese LED companies are shown in the following table (see Table 4 ).

\section{Trends of Global LED Technologies and Markets}

3.1. Trends of Global LED Technologies. There are four directions for the trends of the global LED technologies.

(1) Enhancing Luminous Efficiency. Currently, the average luminous efficiency of high-end products is $150 \mathrm{~lm} / \mathrm{W}$ [4]. In 2012, Japanese Toyoda Gosei Company mass produced and sold $170 \mathrm{~lm} / \mathrm{W}$ LED packaging components, exceeding other companies. According to the goals set by the U.S. DOE, the luminous efficiency of white-light LED components will 
TABLE 3: Rank of revenue of global LED components industry (by country).

\begin{tabular}{|c|c|c|c|c|c|c|c|c|c|c|c|c|}
\hline Year & & 2009 & & & 2010 & & & 2011 & & & $2012(\mathrm{E})$ & \\
\hline Rank & Country & $\begin{array}{c}\text { Revenue } \\
\text { (unit: billion } \\
\text { USD) }\end{array}$ & $\%$ & Country & $\begin{array}{c}\text { Revenue } \\
\text { (unit: billion } \\
\text { USD) }\end{array}$ & $\%$ & Country & $\begin{array}{c}\text { Revenue } \\
\text { (unit: billion } \\
\text { USD) }\end{array}$ & $\%$ & Country & $\begin{array}{c}\text { Revenue } \\
\text { (unit: billion } \\
\text { USD) }\end{array}$ & $\%$ \\
\hline 1 & Japan & 2,746 & $28 \%$ & Taiwan & 4,554 & $28 \%$ & Taiwan & 4,673 & $27 \%$ & Japan & 4,860 & $28 \%$ \\
\hline 2 & Taiwan & 2,719 & $28 \%$ & Japan & 4,089 & $26 \%$ & Japan & 4,33 & $26 \%$ & Taiwan & 4,594 & $26 \%$ \\
\hline 3 & Korea & 1,377 & $14 \%$ & Korea & 3,185 & $20 \%$ & Korea & 3,323 & $20 \%$ & Korea & 3,477 & $20 \%$ \\
\hline 4 & Europe & 1,127 & $12 \%$ & Europe & 1,737 & $11 \%$ & Europe & 1,686 & $10 \%$ & China & 1,610 & $9 \%$ \\
\hline 5 & U.S. & 926 & $9 \%$ & U.S. & 1,337 & $8 \%$ & China & 1,465 & $9 \%$ & Europe & 1,598 & $9 \%$ \\
\hline 6 & China & 838 & $9 \%$ & China & 1,182 & $7 \%$ & U.S. & 1,367 & $8 \%$ & U.S. & 1,364 & $8 \%$ \\
\hline
\end{tabular}

Source: adapted from PIDA (2012) [2].

TABLE 4: Relations between international LED companies and Taiwan LED companies.

\begin{tabular}{|c|c|c|c|}
\hline $\begin{array}{l}\text { International } \\
\text { company }\end{array}$ & Country & U.S. patents & Relations with Taiwanese companies \\
\hline $\begin{array}{l}\text { Philips Lumileds } \\
\text { Lighting Company }\end{array}$ & Netherlands & 4127 & $\begin{array}{l}\text { (i) Epistar Corporation is licensed by the technology of AlInGaP light-emitting } \\
\text { diode from Philips Company. } \\
\text { (ii) Epistar Corporation entered HV LED supply chain of Philips Company } \\
\text { successfully. }\end{array}$ \\
\hline Osram Company & Germany & 643 & $\begin{array}{l}\text { (i) Everlight Corporation is authorized by Osram Company with white and colorful } \\
\text { technologies. } \\
\text { (ii) Epistar Corporation allied with Deltato Company to develop HV LED grain to } \\
\text { get mass orders from Osram Company. }\end{array}$ \\
\hline Cree Company & United States & 567 & $\begin{array}{l}\text { Taiwanese firms, for example, Epistar Corporation, Epitaxy Company, and Genesis } \\
\text { Technology Company, have the pricing advantage, while Cree Company with } \\
\text { strong LED lighting performed decline in } 2011 .\end{array}$ \\
\hline $\begin{array}{l}\text { Nichia } \\
\text { Corporation }\end{array}$ & Japan & 477 & $\begin{array}{l}\text { (i) OPTO Company gained orders of cutting grain from Nichia Corporation. } \\
\text { (ii) Everlight Corporation succeeded in the sue with Nichia Corporation. }\end{array}$ \\
\hline $\begin{array}{l}\text { Toyoda Gosei } \\
\text { Company }\end{array}$ & Japan & 347 & $\begin{array}{l}\text { (i) Epistar Corporation cross-licensed with Toyoda Gosei Company to access LEDs } \\
\text { on III-V semiconductor technology patents in } 2010 . \\
\text { (ii) Epistar Corporation and Toyoda Gosei Company formed joint venture named } \\
\text { TE OPTO Corporation. }\end{array}$ \\
\hline
\end{tabular}

Source: this study.

reach $200 \mathrm{~lm} / \mathrm{W}$ by 2014 , and prices will decline to approximately US $\$ 2 / \mathrm{klm}$. And we expect that the technological progress achieved by companies worldwide will soon surpass this goal.

(2) Extending LED Lifespan. Currently, a LED component can operate for 40,000 to 50,000 hours in its lifetime [4]. For special occasions, where the replacement of the light source is difficult (e.g., the ceilings of factories and airports that are extremely far from the ground), long-life LED light sources are required. The LED components of Toyoda Gosei Company can operate for up to 60,000 hours. Compared with traditional incandescent bulbs, LEDs are far more energyefficient, long-lasting (100,000 hr compared with $1000 \mathrm{hr}$ ), and environmentally friendly [5]. Thus, they are suitable for use in special circumstances and can satisfy the demands of the global market.

(3) Developing High-Voltage (HV) LEDs. Currently, most single LED chips are based on a low voltage of $3 \mathrm{~V}$, but voltage in the mains ranges between $100 \mathrm{~V}$ and $220 \mathrm{~V}$ [4]. Thus, reducing the voltage from the mains will lead to a significant loss of power. Taiwanese Epistar Corporation began developing HV LEDs in the early stage, followed by latecomers Cree Company (in the United Stated) and Seoul Semiconductor LED (in Korea). HV LEDs possess the advantages of a compact size and the ability to be customized into various forms for integration. Thus, they have the potential for largescale deployment in the lighting market over the next 2 to 5 years.

(4) Enhancing the Acceptability of Solar-Powered LED Lighting Technology. LED lanterns powered by batteries, which are charged by grid electricity or small solar panels, have emerged as a cost-competitive alternatives to kerosene and other fuel-based lighting technologies. Solar-powered LED lighting technologies have a niche in rural areas that are off-grid and have no available electricity for the most part [9-13]. Solar-powered LED lights are increasing popularly, because the lower retail price of these lights can make them more affordable to lower-income households. Solar-powered LED lights offer off-grid energy service for rural areas or 
developing countries like Malawi, Zambia, and Cambodia, and so forth.

For the developments of future technologies, solarpowered LED lighting technologies [9-13] can offer the offgrid energy services for the rural area and for the poor, while white LED based PV lighting systems [14] and organic LED lighting technologies $[15,16]$ can continue to be explored in the area of energy saving lighting technologies. Besides, power management and intelligent control [17-19], thermal analysis and optimization [20,21], cooling [22], and reliability issue [23] are also important for LED technology developments. Particularly, solar power, fuel cells, and LEDs combine to light the way towards green economy [24].

3.2. Trends of Global LED Market. The global high-power LED market reached US $\$ 12.5$ billion in 2011, 9.8\% higher than that in 2010 [6]. Specifically, the lighting sector grew from US $\$ 1.2$ billion to US\$1.8 billion, with a growth rate of $44 \%$. According to the market forecasts for the next five years, the market demands for lighting will increase, whereas the market demand for backlight lighting is expected to decline. The use of OLED will increase substantially because of smart phones.

In 2012, the annual revenue for high-power LEDs reached US $\$ 10.1$ billion globally (see Figure 4), with a growth rate of 13.4\%. The market share of Taiwanese, Japanese, and South Korean firms combined amounted to $61.3 \%$ in 2012, and the global LED industry is dominated by Asia $[3,25]$. In 2012, the growth of LED products in China was primarily concentrated on low-power LEDs, with a growth rate of $30 \%$. Among the high-power LED application categories, in 2012, largescale displays using LED backlighting accounted for 34.1\%, followed by lighting applications, which accounted for $16.7 \%$. These figures are estimated to reach $28.7 \%$ and $33.4 \%$ in 2014 , respectively [25].

Currently, because energy-efficient light bulbs are still used extensively, the rate of penetration for LED bulbs was only $5.4 \%$ in 2012 , that is, 1.05 billion bulbs, indicating a significant potential for market growth in the future. The penetration rate of the global LED lighting market is expected to increase from $11.3 \%$ in 2012 to $25.8 \%$ in 2014, with the revenue growing from US $\$ 16.5$ billion in 2012 to US $\$ 41.9$ billion in 2014. Promotional policies and preferential implementations have been introduced in countries worldwide to boost their developments of the LED lighting market. In the general lighting market, LEDs are anticipated to comprise $50 \%$ of the market share in Japan, 30\% in South Korea, and 20\% in China by 2015 [4].

In the rapidly growing LED light bulb market, new products developed in 2012 will replace the standard $60 \mathrm{~W}$ incandescent bulbs. Currently, an LED bulb equivalent to $60 \mathrm{~W}$, with a brightness of $800 \mathrm{~lm}$, prices up to US\$40. The selling price, which can be accepted by most consumers, varies between the different regions: (1) in the Japanese market, the selling price is US\$25; (2) in the European and the U.S. market, the selling price is approximately US $\$ 15$; and (3) in the newly emerging markets, the selling price is approximately US $\$ 7$.

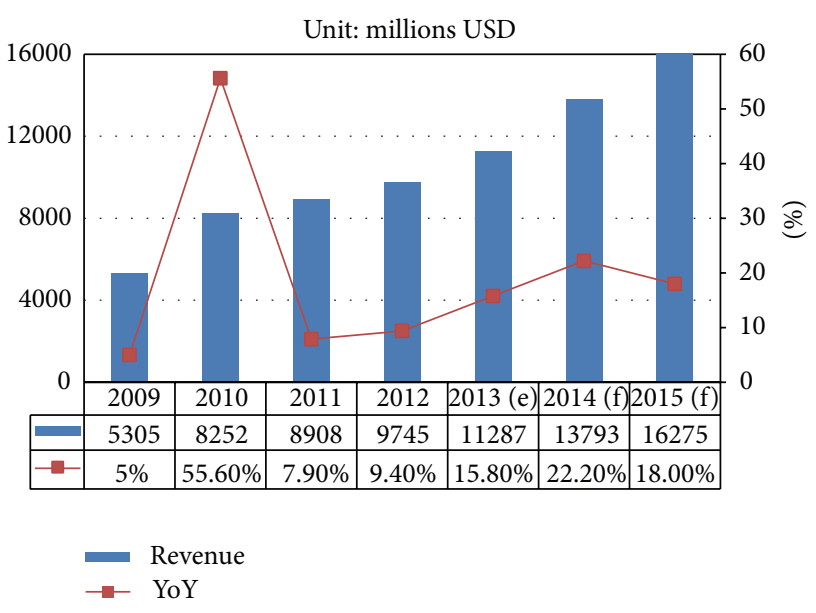

FIGURE 4: 2009-2015 prediction of global high-power LED market. Source: DIGITIMES (2013) [4].

\section{Analysis of Taiwan LED Industry}

4.1. History of Taiwan LED Industry. Taiwanese LED industry has been developed for 40 years (see Table 5). Because of the relatively few obstacles and capital requirements for packaging technology, the downstream package and module sector were first built up by Taiwanese firms in the 1970s. In the 1980s, industrial value chain of Taiwan was extended to include the midstream sector of grains process. In the 1990s, through technological diffusion and investments from U.S. overseas Taiwanese scholars, Taiwanese LED industry reached the developments of upstream sectors of the epitaxial process. In 2001, because of its technological accomplishments and expansion into the South Korean market, Taiwanese LED industry not only successfully branched into the GaN LED market, but also took the leadership of the global LED industry. The history of the industrial developments is as follows.

In 1972, Texas Instruments Incorporation established the first packaging plant in Taiwan. In 1975, Lite-On Technology Corporation established a LED packaging production line and became a pioneer among downstream packaging firms. From 1983, upstream technologies were focused by Taiwanese firms after the Optotech Corporation and Tyntek Corporation were set up and the downstream packaging industry was experiencing substantial growth. In 1996, the Taiwan Industrial Technology Research Institute collaborated with downstream packaging firms to establish a joint venture named Epistar Corporation, which focused on upstream LED processes. After the investments of the MOCVD research and technology transfer provided by several downstream suppliers of Epistar Corporation, a complete LED industrial value chain has been established in Taiwan. In 2005, Epistar Corporation merged with Epitech Corporation and Highlink Technology Corporation. In 2007, Epistar Corporation merged with United Epitaxy Company. In 2009, the Taiwanese government initiated a program called "rising sun" to promote the green energy industry. At that time, the LED and solar photovoltaic industries were considered "the 
TABle 5: The history of Taiwan LED industry.

\begin{tabular}{|c|c|}
\hline Year & Events \\
\hline 1972 & The first packaging plant in Taiwan was set up by the Texas Instruments Incorporation. \\
\hline 1975 & $\begin{array}{l}\text { Lite-On Technology Corporation set up a LED packaging production line and become a pioneer among downstream packaging } \\
\text { firms. }\end{array}$ \\
\hline 1983 & $\begin{array}{l}\text { After the Optotech Corporation and Tyntek Corporation were set up, not only the downstream packaging sector grew } \\
\text { substantially but also upstream technologies were focused by Taiwanese LED firms. }\end{array}$ \\
\hline 1996 & $\begin{array}{l}\text { ITRI collaborated with Epitech Corporation to establish a joint venture named Epistar Corporation, which focused on upstream } \\
\text { LED process. }\end{array}$ \\
\hline 2005 & Epistar Corporation merged with Epitech Corporation. \\
\hline 2009 & LED and solar photovoltaic industries are promoted by a "rising sun" program proposed by Taiwanese government. \\
\hline 2010 & The revenue of Taiwanese LED components reached US $\$ 4,554$ million and ranked top 1 in the world. \\
\hline 2011 & The revenue of Taiwanese LED components reached US $\$ 4,673$ million dollars and ranked top 1 in the world. \\
\hline 2012 & $\begin{array}{l}\text { The "entire Taiwan LED street lighting program" was implemented by Taiwanese government to further stimulate rapid growth } \\
\text { in LED industry. }\end{array}$ \\
\hline
\end{tabular}

Source: this study.

two rising industries" and shortlisted as key programs for development. The revenue of the LED components industry in Taiwan reached US\$4,554 million in 2010, the highest in the world. In 2011, the revenue of LED components industry in Taiwan reached US $\$ 4,673$ million, the highest in the world. In 2012, the "entire Taiwan LED street lighting program" was implemented to further stimulate rapid growth of the LED industry.

4.2. Analysis of Taiwan LED Value Chain. Depending on the manufacturing processes, the LED industry can be divided into three sectors, that is, (1) the upstream epitaxial wafer sector, (2) the midstream grain sector, and (3) the downstream package and module sector. Unlike largescale international manufacturers that adopt vertical integration, Taiwanese companies adopt a division of labor across upstream, midstream, and downstream sectors to form professional cooperation. Because of the low entry barriers of the LED downstream package and module sector, Taiwanese firms penetrated the market from the downstream package and module sector in the early stage and maintained a continual growth after extending to the upstream and midstream sectors. Since the mass production of GaNbased LEDs in Taiwan, to reduce internal costs and increase revenue, the division of labor in the industry was transformed from the formerly trisegmented pattern (covering upstream, midstream, and downstream segments) into a bisegmented pattern (including up-midstream sector of Epi-wafer and grain process and the downstream sector of package and module) (see Figure 5).

Major up- and midmidstream suppliers include Epistar, Huga, FormosaEpitaxy, and Techcore, in which Epistar Corporation is the largest red-light LED suppliers in the world. Downstream suppliers include Everlight, Lite-On, and Kingbright. Also, there are vertically integrated suppliers in Taiwan, such as Lextar Electronics Corporation and Taiwan Semiconductor Manufacturing Company.
For the revenue of the up- and midstream Epi-wafer and grain production, Taiwanese firms ranked top 1 in the world. For the revenue of the downstream package and module production, Taiwanese firms ranked the third in the world, behind only Japan and South Korea. Taiwanese LED packaging products can generally be categorized as SMD LED, Infrared components, and LED displays. The focus of the future market is expected to shift from LED displays to LED lighting, since the growth of the liquid crystal displays (LCD) sales have been sluggish over the past several years.

4.3. Clusters of Taiwan LED Industry. Three science parks are major industrial clusters in Taiwan, namely, Hsinchu Science Park, Central Taiwan Science Park, and Southern Taiwan Science Park (see Figure 6) [2]. These science parks converge into the clusters of the semiconductor and optoelectronic industries, forming a complete industrial value chain ranging from the upstream material and design to the downstream packaging and peripheral devices. Based on the sound foundation in its semiconductor industry, Taiwanese firms enjoy a competitive advantage regarding their talents and technologies in the LED and optoelectronic industry, which built up the highest density of LED epitaxial machinery in the world. Due to being supported by the upstream supply of materials in the semiconductor and optoelectronics industries, Taiwanese firms can effectively reduce the costs and cycle of the developments, thereby playing a significant role in the global LED value chain.

In the Hsinchu Science Park, most suppliers belong to the LED up- and midstream sector of the wafers and grains. Also, there are vertically integrated LED suppliers, which integrated downstream sector of packaging and modeling. In the Central and Southern Taiwan Science Parks, most suppliers belong to the LED up- and midstream sector of the wafer and grain industries.

4.4. Revenue Scale of Taiwan LED Industry. The revenue of Taiwanese LED components industry is ranked the first 


\begin{tabular}{|c|c|c|}
\hline Upstream and midstream & & Downstream \\
\hline Grain & Package & Module \\
\hline $\begin{array}{c}\text { Arima Optoelectronics } \\
\text { Corporation, } \\
\text { HugaOptotech lnc., } \\
\text { Forepl lnc., Highlight } \\
\text { Optoelectronics Inc. } \\
\text { Tekcore Corp., Luxxon } \\
\text { Technology Corporation, } \\
\text { SemiLEDs Corporation, } \\
\text { Genesis Photonics Inc., } \\
\text { SuperNova Optoelectronics } \\
\text { Corporation, } \\
\text { Luxtaltek Corporation, } \\
\text { Nan Ya Photonics Inc., } \\
\text { Epileds Light Tech. Green Future, } \\
\text { Visual Photonics Epitaxy Corp., } \\
\text { Ltd, Shin-Etsu Silicon } \\
\text { Taiwan Corp., } \\
\text { Landmark Optoelectronics } \\
\text { Corporation, GET Corp., } \\
\text { TNYTEK Corporation, } \\
\text { Opto Tech. Corporation, } \\
\text { High Power } \\
\text { Opto. Inc., } \\
\text { Chi Mei Lighting } \\
\text { Technology Corporation, } \\
\text { Lextar Electronics Corporation, } \\
\text { Epistar }\end{array}$ & $\begin{array}{c}\text { Kingbright Electronic, } \\
\text { Rodan (Taiwan) } \\
\text { Ltd, Lite-On Technology, } \\
\text { light tripod } \\
\text { Electronics, Oasistek, } \\
\text { Harvatek, Unity } \\
\text { Opto Technology, BRIGHT LED } \\
\text { industry, Everlight Electronics, } \\
\text { China Semiconductor Corporation, } \\
\text { Advanced Optoelectronic } \\
\text { Technology Inc., } \\
\text { SOLIDLITE, UBLeds, } \\
\text { Apex Science and } \\
\text { Engineering Corp., LightHouse } \\
\text { Technology Inc., } \\
\text { High Power Lighting Corp, } \\
\text { Letex, Daina Electronics Co., } \\
\text { Ltd., Jiann Wa Electronics, Full-Sun } \\
\text { optotech Co., } \\
\text { BUENO Technology Co., } \\
\text { Ltd., Jorlin, ProLightOpto } \\
\text { Technology Co., nElectroics, } \\
\text { Hi-Light Electronic Co., Ltd., } \\
\text { Wellypower, Arima } \\
\text { Lasers Co., } \\
\text { FORWARD, Brightek, } \\
\text { Paragon Semiconductor Lighting } \\
\text { Technology Co., } \\
\text { UPEC, Ligitek } \\
\text { Electronics Co., Ltd., Tong } \\
\text { HsingElectronic, Harvatek, UBLeds, } \\
\text { InterLightOptotech Corporation, } \\
\text { Ledtech Electronics Corp., } \\
\text { Chin-Shi Electronic Materials Ltd., } \\
\text { Edison Opto Corp., LightFuture, } \\
\text { Heliopto, LUSTROUS, Huey Jann } \\
\text { Electronics Industry Co., Ltd., } \\
\text { I-Chiun, JF New Energy, Lextar }\end{array}$ & 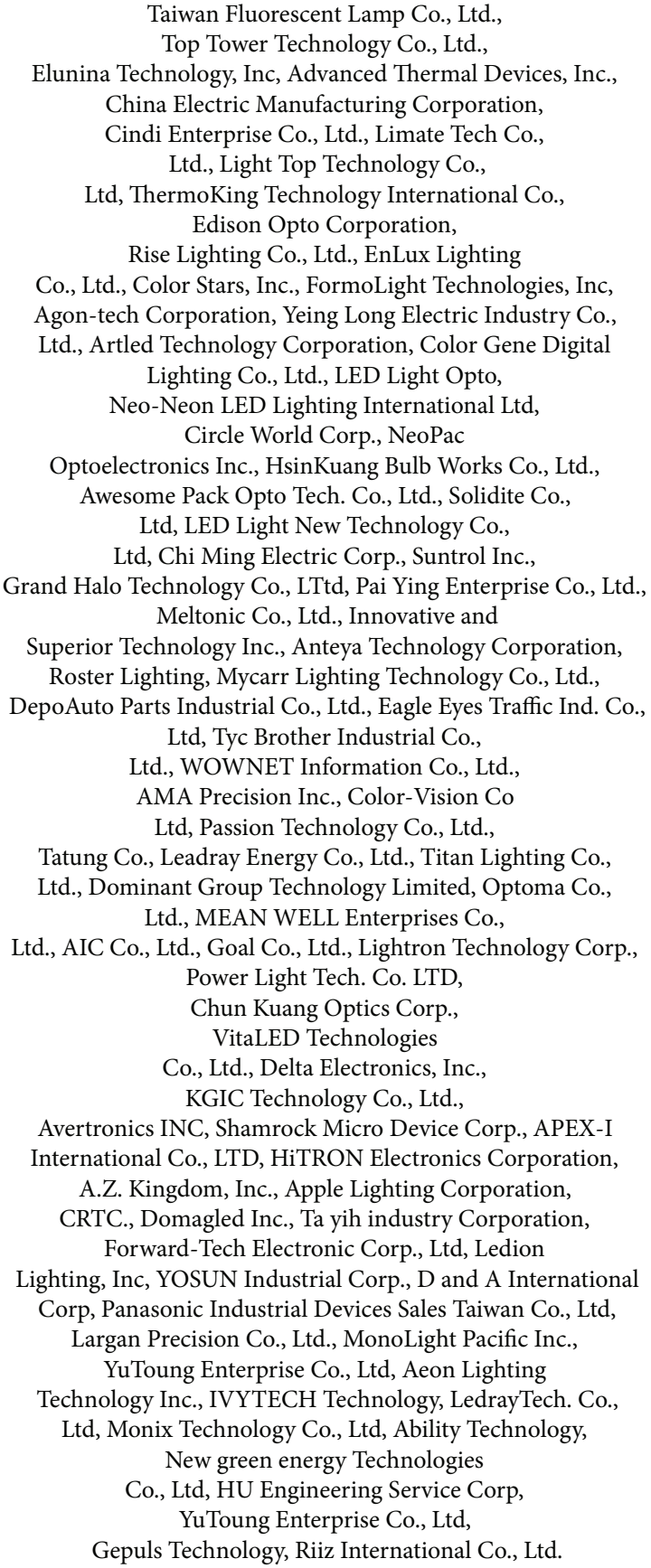 \\
\hline
\end{tabular}

FIGURE 5: Value chain of Taiwanese LED industry. Source: this study.

in the world (see Figure 7) [2]. The revenue of the global LED industry was US\$16,600 million in 2011, with a slight growth of $2.6 \%$ compared to the US\$16,100 million in 2010 . The revenue of Taiwanese LED production reached US $\$ 4,673$ million in 2011. The revenue of Taiwanese downstream sector of packaging and module reached US\$2,877 million in 2011, whereas the revenue of the upstream and midstream sectors of the epitaxial wafer and grain reached US\$1,796 million. 


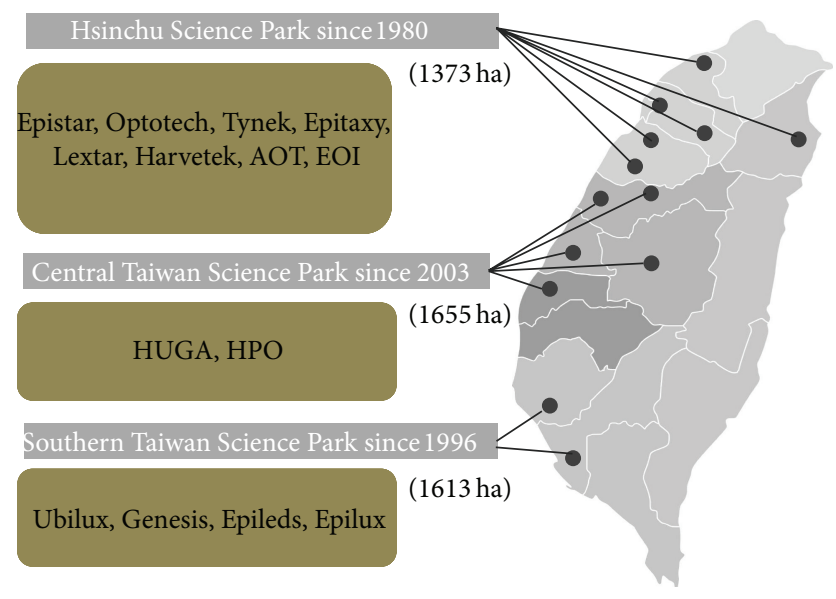

FIgUre 6: LED firms in Taiwan Science Parks. Source: PIDA (2012) [2].

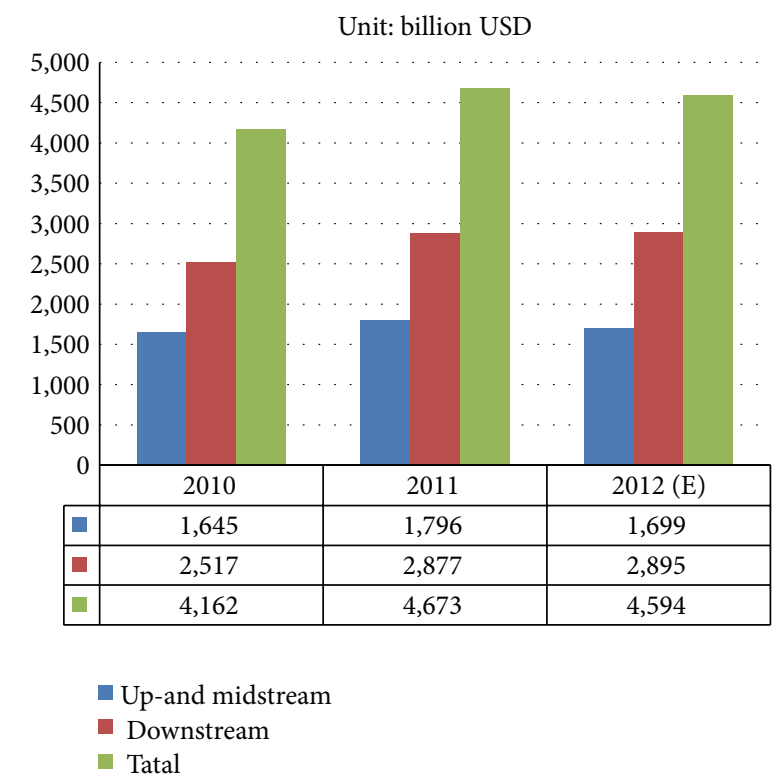

FIGURE 7: Revenue of Taiwanese LED industry. Source: PIDA (2012) [2]. Up- and midstream: Epi-wafer and grain. Downstream: package and module.

In 2012, the global revenue of LED components industry will reach US\$17,503 million and that of Taiwan will be US\$4,594 million by estimation [2].

The revenue of the Taiwanese LED components industry reached $\$ 4,673$ million in 2011, which accounts for approximately $30 \%$ of the global total, making the Taiwanese LED industry a global leader. Analyzing the three main science parks in Taiwan, the LED revenue for the Hsinchu Science Park was the highest at US $\$ 1,367$ million, of which the revenue of the up- and midstream Epi-wafer and grain sector declined by nearly $10.9 \%$, and the revenue of the downstream package and module sector increased by $1.5 \%$. The LED revenue for the Southern Taiwan Science Park was approximately US\$497 million, growing slightly at a rate of
4.7\%. The LED revenue for the Central Taiwan Science Park, which was established after the other two parks, was US\$12 million [2].

4.5. SWOT Analysis of Taiwan LED Industry. SWOT analysis of Taiwanese LED industry is made in this study (see Table 6).

(1) Strength. In 2011, LED revenue in Taiwan was ranked the first place in the world. Known as a kingdom of electronics, a complete value chain was built up in the semiconductor industry in Taiwan. Based on the electronics industry, LED industry can be developed rapidly in Taiwan. Taiwanese firms have invested in its LED industry for 40 years and developed a complete industrial value chain with numerous firms actively involving in upstream, midstream, and downstream segments. Furthermore, because of experienced technologies and managements, Taiwanese firms can provide customized services according to customers' needs. The Taiwanese government has provided significant support to promote the "two rising stars of optoelectronics" policy (the LED and solar photovoltaic industries) because the development of this industry is among those that should be prioritized.

(2) Weakness. Unlike the brand establishment by other largescale international firms from Japan, Korea, Europe, and the United States, Taiwanese firms follow the original equipment manufacturer (OEM) mode. Taiwanese production is primarily export-oriented, and R\&D inputs are relatively limited. Most of the key technologies in Taiwan are restricted by patents held by large-scale international companies in the U.S. and Japan; thus, patent infringement occasionally occurs. Large international firms practice cross-licensing and cooperative development, whereas Taiwanese suppliers rely on the agreements of unilateral authorization from large international companies to obtain key technologies for mass production and sales.

(3) Opportunity. Because governments worldwide have implemented energy-saving policies, the LED industry has developed rapidly in recent years. Improvements in LED performance can be employed extensively in numerous fields with high added value, such as the global adoption of LED backlight displays, landscape lighting, and energy-saving road lighting. Taiwanese LED products are sold at lower prices than those produced in Europe, the United States, and Japan; therefore, they are more competitive in the global LED market.

(4) Threat. Taiwanese suppliers are primarily OEM oriented; thus, their capabilities for the high-end products are relatively weak. Taiwanese enterprises focus more on reducing the costs of manufacturing. In the future, $\mathrm{R} \& \mathrm{D}$ capability should be improved in Taiwan. In recent years, panel manufacturers from South Korea (e.g., LG Electronics and Samsung Electronics) and China are developing rapidly, becoming strong competitors of Taiwanese firms. In addition, traditional lighting products are also competitive products for LED lighting products because of their improved performance and reduced price. 
TABLE 6: SWOT analysis of Taiwan LED industry.

\begin{tabular}{|c|c|}
\hline Strength & Weakness \\
\hline $\begin{array}{l}\text { (1) Rank Top } 1 \text { for LED revenue in 2010, } 2011 . \\
\text { (2) Advantage of Taiwanese electronics industry. } \\
\text { (3) A complete value chain of Taiwanese semiconductor industry was } \\
\text { built up. } \\
\text { (4) A complete value chain of Taiwanese LED industry was built up. } \\
\text { (5) Taiwanese firms have experience in technologies and } \\
\text { managements. } \\
\text { (6) Taiwanese firms can provide customized service. } \\
\text { (7) The LED has been supported by the Taiwanese government. }\end{array}$ & $\begin{array}{l}\text { (1) Taiwanese firms follow the OEM mode. } \\
\text { (2) Taiwanese firms are Weak in establishing branding. } \\
\text { (3) R\&D inputs are relatively limited by Taiwanese firms. } \\
\text { (4) Taiwanese firms focus more on cost down in manufacturing. } \\
\text { (5) Key technologies are restricted by patents held by } \\
\text { international companies. } \\
\text { (6) Taiwanese production is mostly exported. } \\
\text { (7) Taiwanese suppliers rely on unilateral authorization from } \\
\text { international companies to obtain key technologies. }\end{array}$ \\
\hline Opportunity & \\
\hline $\begin{array}{l}\text { (1) Governments worldwide have implemented energy-saving } \\
\text { policies. } \\
\text { (2) Improvements in LED performance can be employed in many } \\
\text { fields, for example, energy-saving lighting. } \\
\text { (3) Taiwanese LED products have lower price in the global LED } \\
\text { market. } \\
\text { (4) Emerging markets are increasing. }\end{array}$ & $\begin{array}{l}\text { (1) Taiwanese suppliers are primarily OEM oriented. } \\
\text { (2) Capabilities for high-end products are relatively weak. } \\
\text { (3) Korean and Chinese Panel manufacturers are developing } \\
\text { rapidly, becoming strong competitors of Taiwanese firms. } \\
\text { (4) Traditional lighting products are competitive products for } \\
\text { LED lighting products. }\end{array}$ \\
\hline
\end{tabular}

Source: this study.

\section{Conclusion}

Taiwanese firms play an important role in the global LED components industry. The advantages of its electronics industry and the industrial clusters have enabled Taiwanese firms to expand the LED industry rapidly. A complete value chain was established in Taiwanese LED industry, with the vertical disintegration across upstream, midstream, and downstream segments. Up- and midstream suppliers specialize in the production of the LED wafers and grains, and downstream suppliers specialize in the production of the LED packaging and module. Taiwanese LED firms at various sections of the value chain have unique specialties and efficient operations to achieve the economies of scope. A number of firms with significantly financial support achieve the economies of scale by vertically integrating their operations. Taiwanese LED suppliers have an important role in the global LED value chain because of their comprehensive division of labor and excellent manufacturing capacities.

\section{Conflict of Interests}

The author declares that there is no conflict of interests regarding the publication of this paper.

\section{Acknowledgment}

The author particularly thank Taiwan National Science Council for financial support (Grants NSC 101-3113-S-003014- and NSC 100-3113-S-003-014-). The author owes special thanks to the research teams who collected the data for this paper.

\section{References}

[1] Topology Research Institute, 2011-2012 Forecast of Global LED Revenue, Topology Research Institute, Taipei, Taiwan, 2012.
[2] Photonics Industry \& Technology Development Association, The 2012 Yearbook of LED Market, Industrial Applications, and Standard Developments, Photonics Industry \& Technology Development Association, Taipei, Taiwan, 2012.

[3] H. J. Round, “A note on carborundum," Electrical World, vol. 49, p. 309, 1907.

[4] DIGITIMS, 2009-2015 Prediction of Global High-Power LED Market, DIGITIMS, Taipei, Taiwan, 2014.

[5] J. A. Mathews, "Latecomer strategies for catching-up: the cases of renewable energies and the LED programme," Technological Learning, Innovation and Development, vol. 1, no. 1, pp. 34-42, 2007.

[6] Strategies Unlimited, The Worldwide Market for LEDs Market Review and Forecast, Strategies Unlimited, Silicon Valley, NC, USA, 2014.

[7] Photonics Industry \& Technology Development Association, 2011-2012 Global Photonics Markets and Taiwan Photonics Industry, Photonics Industry \& Technology Development Association, Taipei, Taiwan, 2012.

[8] Y. Chen and B. Chen, "Utilizing patent analysis to explore the cooperative competition relationship of the two LED companies: Nichia and Osram," Technological Forecasting and Social Change, vol. 78, no. 2, pp. 294-302, 2011.

[9] R. Pode, "Solution to enhance the acceptability of solar-powered LED lighting technology," Renewable and Sustainable Energy Reviews, vol. 14, no. 3, pp. 1096-1103, 2010.

[10] E. Adkins, S. Eapen, F. Kaluwile, G. Nair, and V. Modi, “Offgrid energy services for the poor: introducing LED lighting in the Millennium Villages Project in Malawi," Energy Policy, vol. 38, no. 2, pp. 1087-1097, 2010.

[11] K. Kornbluth, B. Pon, and P. Erickson, "An investigation of the cost and performance of a solar-powered LED light designed as an alternative to candles in Zambia: a project case study," Renewable and Sustainable Energy Reviews, vol. 16, no. 9, pp. 6737-6745, 2012.

[12] B. Huang, C. Chen, P. Hsu, W. Tseng, and M. Wu, "Direct battery-driven solar LED lighting using constant-power control," Solar Energy, vol. 86, no. 11, pp. 3250-3259, 2012. 
[13] B. J. Huang, M. S. Wu, P. C. Hsu, J. W. Chen, and K. Y. Chen, "Development of high-performance solar LED lighting system," Energy Conversion and Management, vol. 51, no. 8, pp. 1669$1675,2010$.

[14] O. S. Sastry, V. K. Devi, P. C. Pant, G. Prasad, R. Kumar, and B. Bandyopadhyay, "Development of white LED based PV lighting systems," Solar Energy Materials and Solar Cells, vol. 94, no. 9, pp. 1430-1433, 2010.

[15] N. T. Kalyani and S. J. Dhoble, "Organic light emitting diodes: energy saving lighting technology-a review," Renewable and Sustainable Energy Reviews, vol. 16, no. 5, pp. 2696-2723, 2012.

[16] Y. Kajikawa and Y. Takeda, "Citation network analysis of organic LEDs," Technological Forecasting and Social Change, vol. 76, no. 8, pp. 1115-1123, 2009.

[17] O. Krejcar and R. Frischer, "Smart intelligent control of current source for high power LED diodes," Microelectronics Journal, vol. 44, no. 4, pp. 307-314, 2013.

[18] B. Huang, C. Chen, C. Ong, B. Du, and P. Hsu, "Development of constant-power driving control for light-emitting-diode (LED) luminaire," Applied Thermal Engineering, vol. 50, no. 1, pp. 645651, 2013.

[19] X. Lee, C. Lin, Y. Chang, H. Chen, and C. Sun, "Power management of direct-view LED backlight for liquid crystal display," Optics and Laser Technology, vol. 46, no. 1, pp. 142-144, 2013.

[20] T. Cheng, X. Luo, S. Huang, and S. Liu, “Thermal analysis and optimization of multiple LED packaging based on a general analytical solution," International Journal of Thermal Sciences, vol. 49, no. 1, pp. 196-201, 2010.

[21] J. Wang, R. Wang, T. Chang, and D. Hwang, "Development of 30Watt high-power LEDs vapor chamber-based plate," International Journal of Heat and Mass Transfer, vol. 53, no. 19-20, pp. 3990-4001, 2010.

[22] I. Y. Chen, M. Guo, K. Yang, and C. Wang, "Enhanced cooling for LED lighting using ionic wind," International Journal of Heat and Mass Transfer, vol. 57, no. 1, pp. 285-291, 2013.

[23] M. Chang, D. Das, P. V. Varde, and M. Pecht, "Light emitting diodes reliability review," Microelectronics Reliability, vol. 52, no. 5, pp. 762-782, 2012.

[24] S. Dow, "Fuel cells and LEDs combine to light the way towards the green economy," Fuel Cells Bulletin, vol. 2011, no. 8, pp. 12-14, 2011.

[25] LEDinside, Analysis of 2013 LED Lighting, LEDinside, Taipei, Taiwan, 2014 

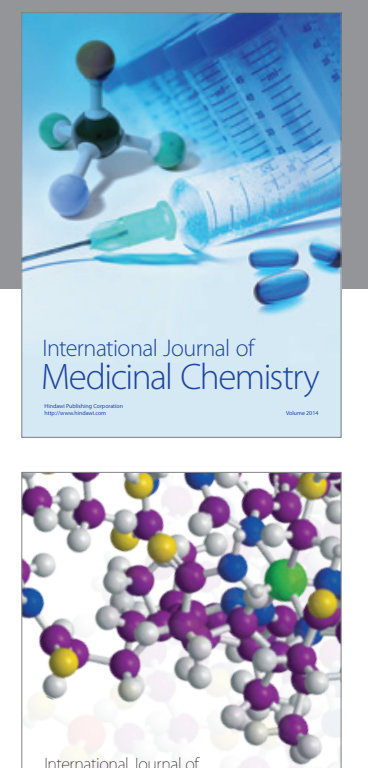

\section{Carbohydrate} Chemistry

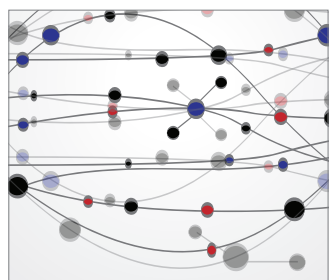

The Scientific World Journal
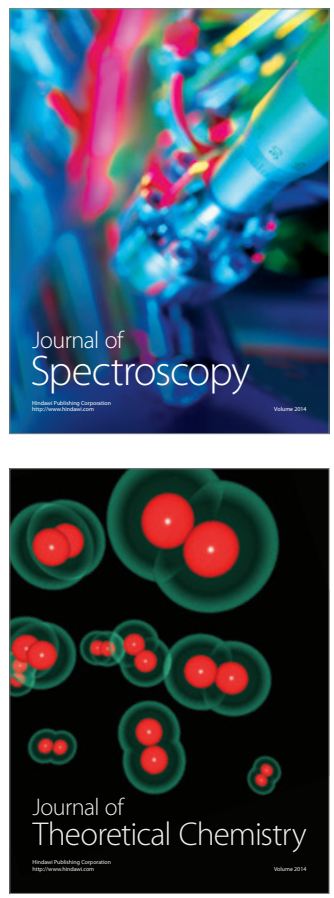
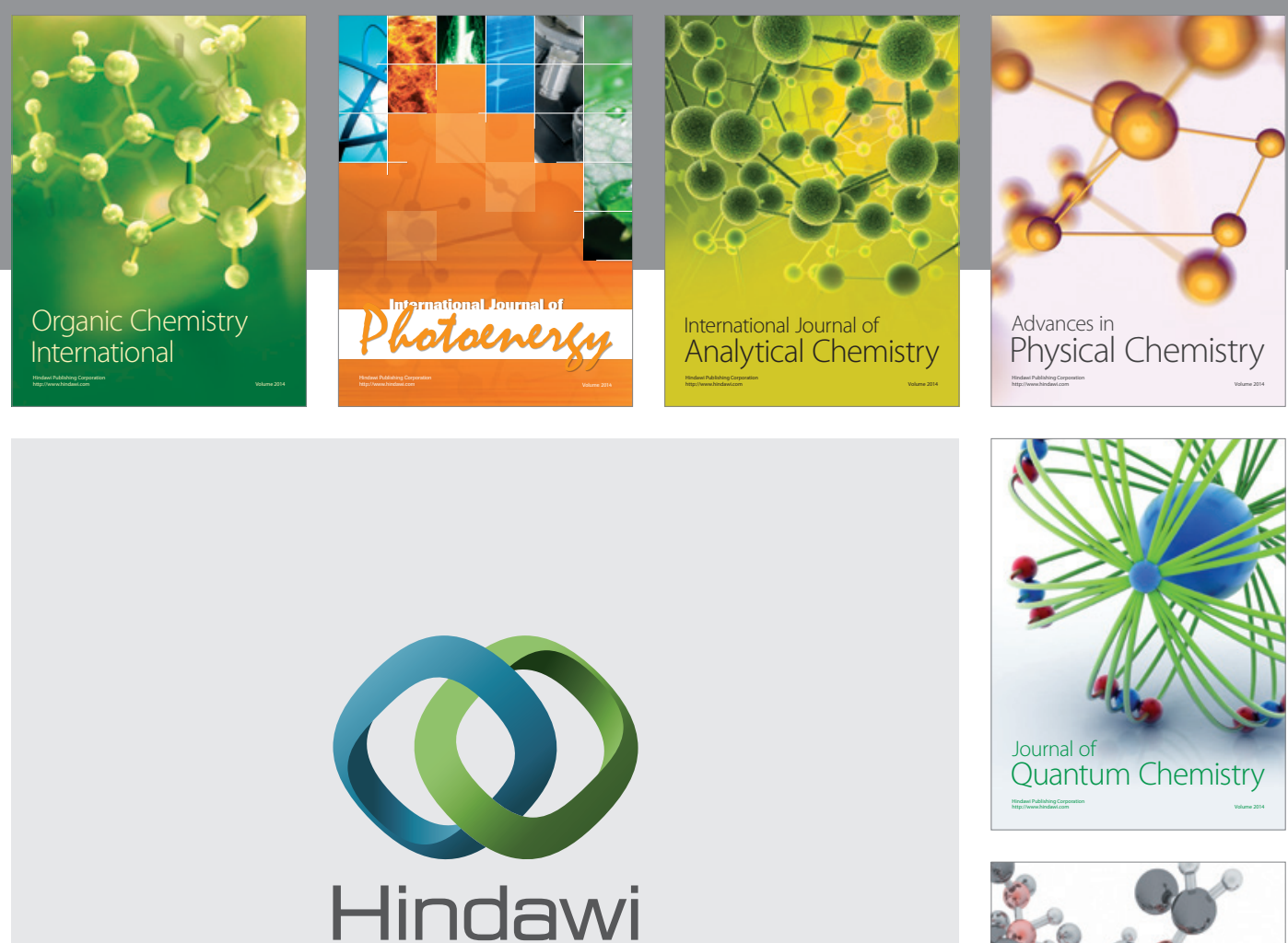

Submit your manuscripts at

http://www.hindawi.com

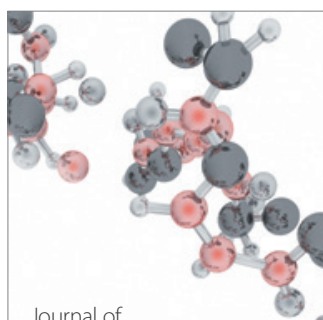

Analytical Methods

in Chemistry

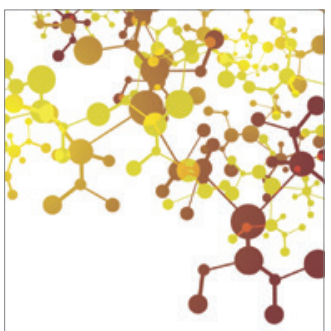

Journal of

Applied Chemistry

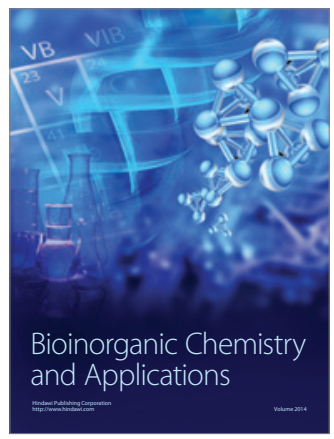

Inorganic Chemistry
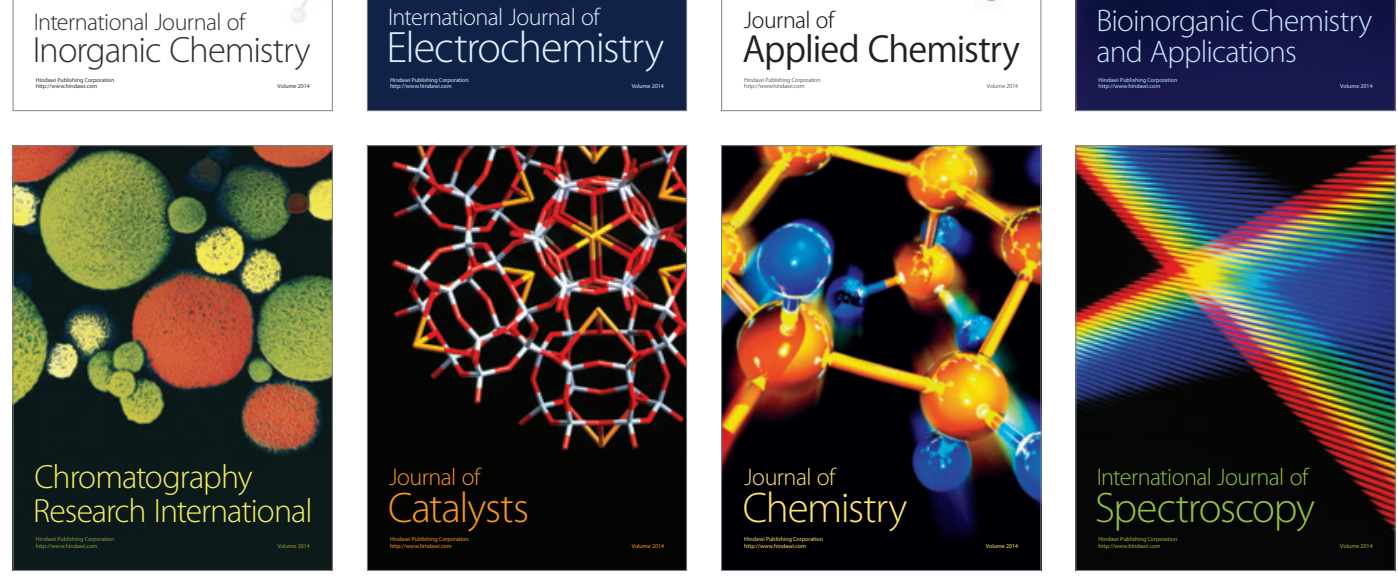